\title{
Biocompatibility and biomineralization of the experimental nanoparticulate mineral trioxide aggregate (MTA)
}

\author{
Biocompatibilidade e biomineralização do agregado de trióxido mineral (MTA) nanoparticulado \\ experimental
}

Biocompatibilidad y biomineralización del agregado de trióxido mineral (MTA) nanoparticulado experimental

\begin{abstract}
To investigate the tissue response and the biomineralization ability of the experimental nanoparticulate mineral trioxide aggregate compared to grey MTA and Fillapex MTA. Polyethylene tubes containing materials or empty tubes for control were inserted into the subcutaneous tissues of 30 rats. After 7, 15, 30, 60, and 90 days, the rats were killed and the tubes were removed for analysis using hematoxylin-eosin staining, von Kossa staining, and under polarized light. Inflammation was graded through a score system; the biomineralization ability was recorded as present or absent. The results were statistically analyzed using the Kruskal-Wallis test $(\mathrm{p}<0.05)$. On days 7 and 15 there was a significant difference between the Nano MTA (median score of 3) and MTA Fillapex groups (median score of 4), being MTA Fillapex the material with the highest number of inflammatory cells. At 30, 60, and 90 days there was no difference between the Nano MTA, Grey MTA, and MTA Fillapex groups. All materials induced the formation of mineralized tissue in all experimental periods. Nano MTA showed biocompatibility and biomineralization similar to grey MTA Angelus.
\end{abstract}

Keywords: Materials testing; Nanoparticles; Endodontics; Root canal therapy. 


\begin{abstract}
Resumo
Investigar a resposta tecidual e a capacidade de biomineralização do agregado de trióxido mineral experimental nanoparticulado em comparação com o MTA cinza e o MTA Fillapex. Tubos de polietileno contendo materiais ou tubos vazios para controle foram inseridos no tecido subcutâneo de 30 ratos. Após 7, 15, 30, 60 e 90 dias, os ratos foram eutanasiados e os tubos removidos para análise por meio de coloração com hematoxilina-eosina, coloração de von Kossa e sob luz polarizada. A inflamação foi avaliada por meio de um sistema de scores; a capacidade de biomineralização foi registrada como presente ou ausente. Os resultados foram analisados estatisticamente pelo teste de Kruskal-Wallis $(\mathrm{p}<0.05)$. Nos dias 7 e 15 houve diferença significativa entre os grupos Nano MTA (escore médio 3) e MTA Fillapex (escore médio 4), sendo o MTA Fillapex o material com maior número de células inflamatórias. Aos 30, 60 e 90 dias não houve diferença entre os grupos Nano MTA, Gray MTA e MTA Fillapex. Todos os materiais induziram a formação de tecido mineralizado em todos os períodos experimentais. O Nano MTA apresentou biocompatibilidade e biomineralização semelhantes ao MTA Angelus cinza.
\end{abstract}

Palavras-chave: Teste de materiais; Nanopartículas; Endodontia; Tratamento do canal radicular.

\title{
Resumen
}

Investigar la respuesta tisular y la capacidad de biomineralización del agregado experimental de trióxido mineral nano particulado en comparación con el Gray MTA y el Fillapex MTA. Se insertaron tubos de polietileno que contenían los materiales os tubos vacíos como control en los tejidos subcutáneos de 30 ratas. Después de 7, 15, 30,60 y 90 días, se sacrificaron las ratas y se retiraron los tubos para su análisis usando tinción con hematoxilina-eosina, tinción de von Kossa y bajo luz polarizada. La inflamación se clasificó mediante un sistema de puntuación; la capacidad de biomineralización se registró como presente o ausente. Los resultados se analizaron estadísticamente mediante la prueba de Kruskal-Wallis ( $\mathrm{p}<0,05$ ). Los días 7 y 15 hubo diferencia significativa entre los grupos Nano MTA (puntuación media de 3) y MTA Fillapex (puntuación media de 4), siendo MTA Fillapex el material con mayor número de células inflamatorias. A los 30, 60 y 90 días no hubo diferencia entre los grupos Nano MTA, Gray MTA y MTA Fillapex. Todos los materiales indujeron la formación de tejido mineralizado en todos los períodos experimentales. Nano MTA mostró biocompatibilidad y biomineralización similar al Gray MTA Angelus.

Palabras clave: Ensayo de materiales; Nanopartículas; Endodoncia; Tratamiento del conducto radicular.

\section{Introduction}

Biocompatible materials able to induce the development of biomineralized tissue are of great interest in endodontic clinical applications such as root perforations (Hashem \& Hassanien, 2008), root-end fillings in apical surgeries (Baek, Plenk, \& Kim, 2005), pulp capping (Farsi, Alamoudi, Balto, \& Al Mushayt, 2006), apical plug in apexifications (Simon, Rilliard, Berdal, \& Machtou, 2007), and as a coronal barrier in revascularization (Moreno-Hidalgo, Caleza-Jimenez, MendozaMendoza, \& Iglesias-Linares, 2014). All of these procedures imply contact with living tissues and body fluids, an environment that may affect the physical aspects of the employed material (Nekoofar, Stone, \& Dummer, 2010).

Materials based on mineral trioxide aggregate (MTA) are the gold standard for the aforementioned cases (Parirokh, Torabinejad, \& Dummer, 2018; Torabinejad, Parirokh, \& Dummer, 2018). These materials with a composition largely based on Portland cement components exhibit a hydrophilic nature, enabling its application even in the presence of moisture, once the main elements are tricalcium and dicalcium silicate, tricalcium aluminate, tricalcium oxide, and radiopacifying agents, such as bismuth oxide (J. Camilleri, 2008).

Although it is a material of excellent biological properties, some physicochemical and working properties are lacking. As a result, infinite modifications and preparations have been developed and tested to circumvent these drawbacks. However, none of these new modifications presents powders in a nano-sized, that is particles with 1/1.000 of a micron. Nano-sized particles are of interest because of the high surface-to-volume ratio versus micron-sized particles. The surface-to-volume ratio changes from less than $10 \%$ for micron-sized particles to more than $50 \%$ for nanoparticles, which is essential because a higher surface-to-volume ratio can dramatically increase reactivity, such as hydration and MTA microhardness (Josette Camilleri, 2014).

Hence, this study evaluated a nanoparticulate mineral trioxide aggregate (Nano MTA), analyzing its in vivo reaction in the subcutaneous tissue of rats, and its power to induce mineralization assessed by von Kossa staining and structures 
birefringent to polarized light. Grey MTA and MTA Fillapex were used for comparison.

\section{Methodology}

\section{Animals}

Thirty male Wistar rats aged 3 months were used in this study. Sample size estimates were based on data from previous studies using six animals per group (de Azevedo Queiroz et al., 2018; Viola et al., 2012). They were arranged into five groups, each group corresponding to an experimental time: 7, 15, 30, 60 and 90 days. The rats were kept in temperaturecontrolled housings receiving water and diet ad libitum. Animal care was provided according to the Ethics Committee of Araçatuba School of Dentistry-UNESP for animal use, which was approved before the beginning of the experiments (FOA no. 374-2017) We performed the study following the Animal Research Reporting In Vivo Experiment (ARRIVE) guidelines.

\section{Surgical procedures}

Polyethylene tubes (Abbott Labs, São Paulo, Brazil) with a 1.0-mm internal diameter, 1.6-mm outside diameter, and 10.0-mm length were filled with Nano MTA (UNESP, Ilha Solteira, Brazil), grey MTA (Angelus, Londrina, Brazil), MTA Fillapex (Angelus) prepared according to the company's guidelines. Empty tubes were used as control. The surgical procedure was performed according to previous studies (L. Cosme-Silva et al., 2019). The rats were anesthetized with ketamine (87 $\mathrm{mg} / \mathrm{kg}$ Francotar; Virbac do Brasil, Roseira, Brazil) and xylazine (13 mg/kg Rompum; Bayer S A, São Paulo, Brazil) administered intramuscularly (Dal-Fabbro et al., 2019); their dorsal part was shaved, the skin disinfected with 5\% iodine solution, and a 2.0-cm incision was made in a head-to-tail direction with a \#15 Bard-Parker blade (BD, Franklin Lakes, USA). The skin was reflected to create four pockets around the incision into which the tubes filled with each material and the empty tube were randomly implanted. The skin was closed with a 4.0 silk suture (Ethicon 4.0-Johnson \& Johnson, São Paulo, Brazil).

\section{Histological analysis}

At the $7,15,30,60$, and 90 days after implantation, the rats were euthanized by an excessive dose of anaesthetic solution: sodium thiopental (Thiopentax; Cristalia, Itapira, Brazil), and the tubes with surrounding tissue were removed, fixed in $10 \%$ formalin solution $(\mathrm{pH}=7.0)$, cut transversely in halves, and one half processed with paraffin (Leopoldo Cosme-Silva, Renan Dal-Fabbro, et al., 2019). Serial sections 5-mm thick were obtained and stained with hematoxylin-eosin, whereas 10$\mathrm{mm}$ sections were processed by von Kossa staining or directly examined under polarized light. Histological slices were evaluated under light-field illumination through a microscope with 400x magnification (DM 4000 B; Leica, Wetzlar, Germany) by a single calibrated investigator. Haematoxylin-eosin-stained inflammatory cells close to the material was scored as follows: 1 , no or few inflammatory cells and no reaction; 2 , less than 25 cells and mild reaction; 3, between 25 and 125 cells and moderate reaction; and 4, 125 or more cells and severe reaction (Leopoldo Cosme-Silva, Francine Benetti, et al., 2019). Biomineralization were assessed through von Kossa and birefringent structures to the polarized light, being recorded as present or absent (Cosme-Silva et al., 2020; Sales et al., 2021).

\section{Statistical analysis}

Using the GraphPad Prism (version 8.0) software (GraphPad Software Inc, La Jolla, USA), the Kruskal-Wallis test was performed, followed by Dunn's test. Values of $\mathrm{p}<0.05$ were considered significant. 


\section{Results and Discussion}

\section{Histological Analysis}

Representative images of the groups can be observed in Figure 1. On days 7 and 15 there was a significant difference between the groups Nano MTA (median score of 3) and MTA Fillapex (median score of 4), being MTA Fillapex the material with the highest number of inflammatory cells in the fibrous capsule ( $\mathrm{p}<0.05)$. Compared to the gold standard (Grey MTA Angelus), Nano MTA demonstrated a similar inflammatory reaction ( $\mathrm{p}>0.05$ ). After 15 days, it was possible to observe a reduction on the inflammatory infiltrate in all groups, until they reach a mild inflammatory response at 90 days. At 30,60 and 90 days there was no difference between the groups Nano MTA, Grey MTA, and MTA Fillapex (p > 0.05). Regarding the biomineralization, with exception of the control group, all materials induced the formation of mineralized tissue in all experimental periods, evidenced by the presence of structures darkly stained by the Von Kossa technique and the birefringent structures observed under polarized light Figure 2, Table 1.

Table 1: Inflammatory Score and Biomineralization Ability (\%) of all groups. *Different letters indicate statistical difference among the materials in the same time period $(\mathrm{P}<0.05)$.

\begin{tabular}{|c|c|c|c|c|c|c|c|}
\hline \multirow{2}{*}{ Time / P value } & \multirow{2}{*}{ Groups } & \multicolumn{4}{|c|}{ Inflammatory SCORE } & \multirow{2}{*}{ Median } & \multirow{2}{*}{$\begin{array}{c}\text { Biomineralization } \\
\text { ability (\%) }\end{array}$} \\
\hline & & $\mathbf{1}$ & 2 & 3 & 4 & & \\
\hline \multirow{5}{*}{7 days $/ p=0.01$} & Nano MTA ${ }^{A}$ & 0 & 0 & 5 & 1 & 3 & 100 \\
\hline & Grey MTA A & 0 & 0 & 5 & 1 & 3 & 100 \\
\hline & & & & & & & \\
\hline & MTA Fillapex ${ }^{\text {B }}$ & 0 & 0 & 0 & 6 & 4 & 100 \\
\hline & Control $\mathrm{AB}$ & 0 & 0 & 4 & 2 & 3 & 0 \\
\hline \multirow{4}{*}{15 days $/ p=0.01$} & Nano MTA ${ }^{\text {A }}$ & 0 & 3 & 3 & 0 & 2.5 & 100 \\
\hline & Grey MTA ${ }^{\mathrm{A}}$ & 0 & 3 & 3 & 0 & 2.5 & 100 \\
\hline & MTA Fillapex ${ }^{\text {в }}$ & 0 & 0 & 2 & 4 & 4 & 100 \\
\hline & Control ${ }^{\mathrm{A}}$ & 0 & 3 & 3 & 0 & 2.5 & 0 \\
\hline \multirow{4}{*}{30 days $/ p=0.29$} & Nano MTA ${ }^{A}$ & 1 & 5 & 0 & 0 & 2 & 100 \\
\hline & Grey MTA A & 1 & 5 & 0 & 0 & 2 & 100 \\
\hline & MTA Fillapex A & 0 & 4 & 2 & 0 & 2 & 100 \\
\hline & Control ${ }^{\mathrm{A}}$ & 2 & 3 & 1 & 0 & 2 & 0 \\
\hline \multirow{4}{*}{60 days $/ p=0.78$} & Nano MTA ${ }^{A}$ & 2 & 4 & 0 & 0 & 2 & 100 \\
\hline & Grey MTA A & 3 & 3 & 0 & 0 & 1.5 & 100 \\
\hline & MTA Fillapex A & 2 & 3 & 1 & 0 & 2 & 100 \\
\hline & Control A & 3 & 3 & 0 & 0 & 1.5 & 0 \\
\hline
\end{tabular}


Research, Society and Development, v. 10, n. 5, e27710514866, 2021

(CC BY 4.0) | ISSN 2525-3409 | DOI: http://dx.doi.org/10.33448/rsd-v10i5.14866

\begin{tabular}{|c|c|c|c|c|c|c|c|}
\hline \multirow{4}{*}{90 days $/ \mathrm{p}=0.88$} & Nano MTA ${ }^{A}$ & 4 & 2 & 0 & 0 & 1 & 100 \\
\hline & Grey MTA ${ }^{\text {A }}$ & 4 & 2 & 0 & 0 & 1 & 100 \\
\hline & MTA Fillapex A & 3 & 3 & 0 & 0 & 1.5 & 100 \\
\hline & Control A & 3 & 3 & 0 & 0 & 1.5 & 0 \\
\hline
\end{tabular}

Source: Authors.

Figure 1: Representative images of the subcutaneous tissue reactions in the Nano MTA (A, E), Grey MTA (B, F), MTA Fillapex $(\mathrm{C}, \mathrm{G})$ and Control groups (D, H). Presence of moderate inflammatory cell infiltration (orange arrows) in (A, B, D) and severe (black arrow) in (C) at 7 days. Presence of mild inflammatory cell infiltration (E, F, H) and moderate/severe (G) at 30 days. (A-H) Hematoxylin-eosin staining, 100X.

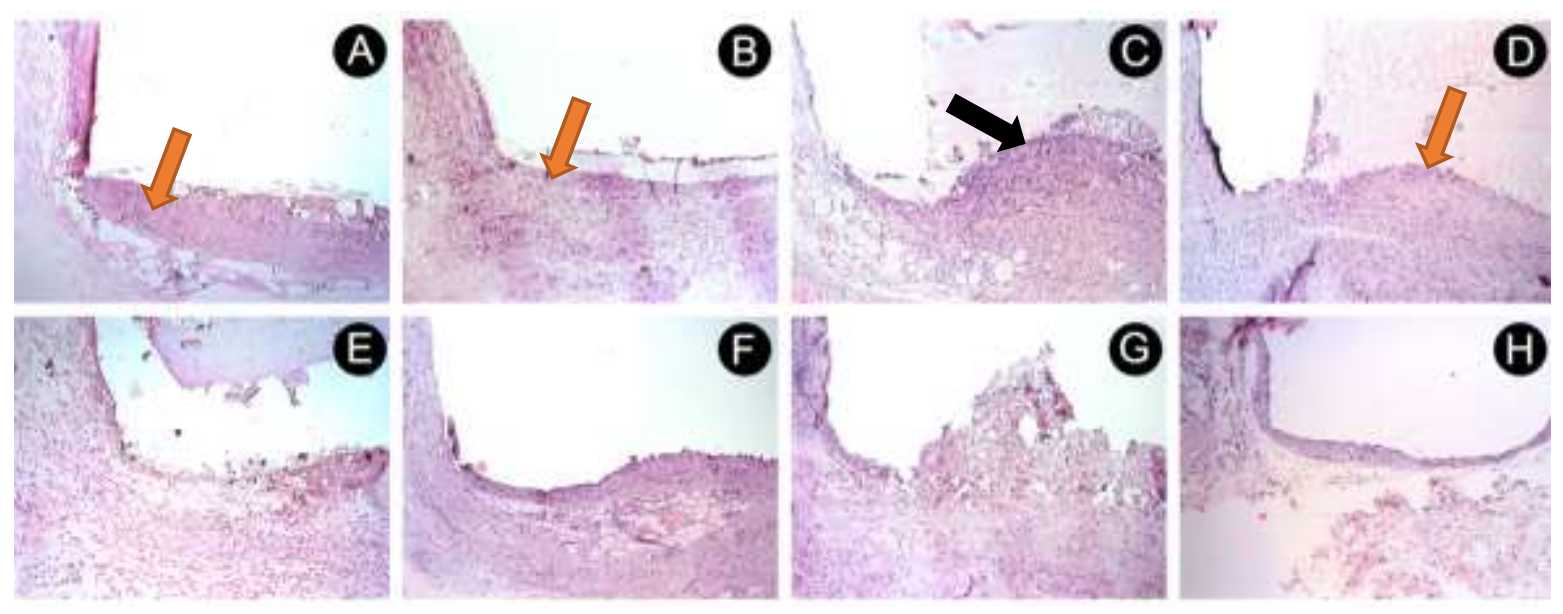

Source: Authors.

Figure 2: Representative images of the subcutaneous tissue reactions in the Nano MTA (I, M), Grey MTA (J, N), MTA Fillapex $(\mathrm{K}, \mathrm{O})$ and Control groups $(\mathrm{L}, \mathrm{P})$. Absence of positive structures for von Kossa and absence of birefringent structures to polarized light $(\mathrm{L}, \mathrm{P})$ for the Control group at all time periods (90 days in the figure). All the other three materials showed Von Kossa-positive staining $(\mathrm{I}, \mathrm{J}, \mathrm{K})$ and granulations birefringent to polarized light $(\mathrm{M}, \mathrm{N}, \mathrm{O})$ near the tube opening at all time periods (90 days in the figure). (A-H) Hematoxylin-eosin staining, 100X; (I-L) staining according to the von Kossa technique, 100X; (M-P) polarized light visualization, 100X.
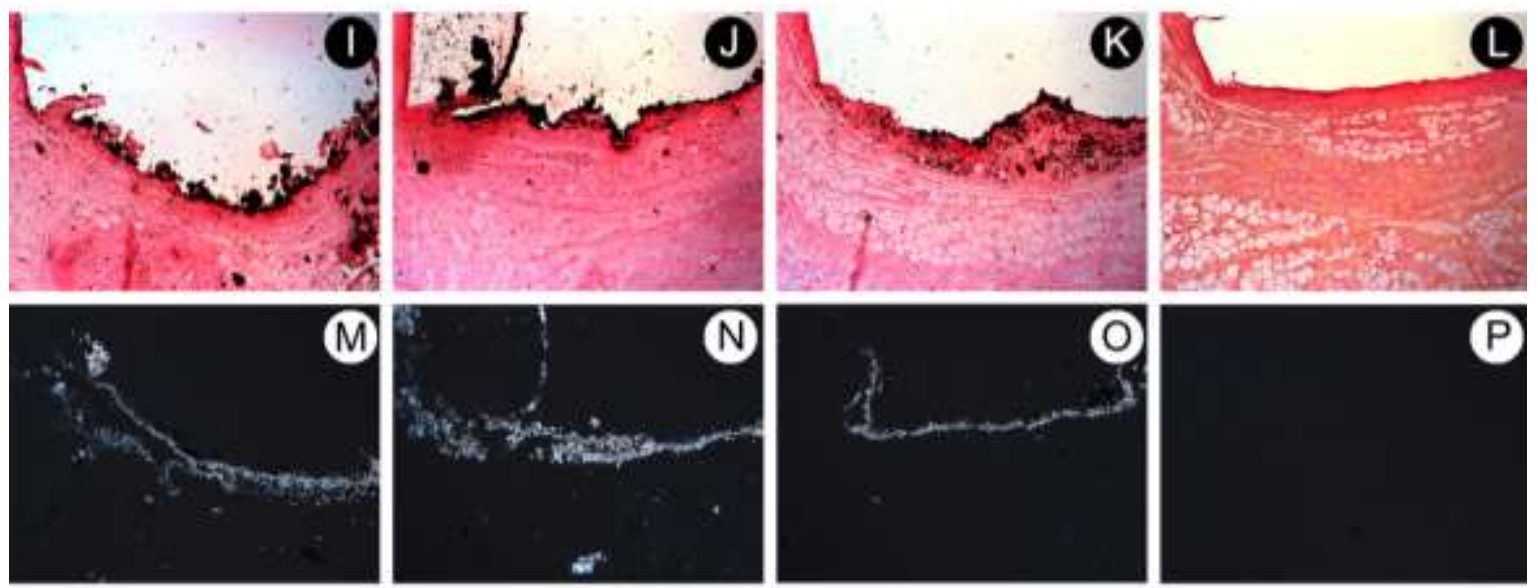

Source: Authors. 
Mineral trioxide aggregate (MTA) is the primary hydraulic calcium silicate cement patented for endodontic applications and the most well known and most thoroughly investigated of all the hydraulic calcium cements available to date. It is a clinker-derived Portland cement composed of different phases, including tricalcium silicate, dicalcium silicate, tricalcium aluminate, tetracalcium aluminoferrite and calcium sulphate, as well as bismuth oxide as a radiopacifier (Josette Camilleri, 2014).

The placement of the materials into the subcutaneous tissue of rats is considered a standardized and valid test for biocompatibility (Olsson, Sliwkowski, \& Langeland, 1981), analyzing the inflammatory tissue response through hematoxylineosin staining (Bueno et al., 2018), within time periods of the endorsed standard practices for biological evaluation of dental materials ("Recommended standard practices for biological evaluation of dental materials. Federation Dentaire International, Commission of Dental Materials, Instruments, Equipment and Therapeutics," 1980), being used widely across the world. The polyethylene tubes delimit the dispersion of the material to a restricted area, enabling comparing the dispersion of the material in the tooth apex to the periapical tissues.

Biocompatible materials are not inert but should not cause an unacceptable physiological response in the host when compared to other biocompatible materials already documented (J. Camilleri, 2008). The results observed with Nano MTA were similar to the grey MTA and control groups. A moderate chronic inflammatory response at days 7 and 15 , reducing over time. Positive von Kossa areas and birefringent structures under polarized light were also observed in all groups, except for the Control, showing that the material stimulated the formation of mineralized tissue in subcutaneous tissues of rats probably via the calcium carbonate formation from the calcium of the material and carbon dioxide from the surrounding tissue (Holland et al., 1999).

One possible reason for the adequate biological properties of the Nano MTA material containing is their high similarity to the conventional MTA composition, differing only in particle size. This change in particle size can play an important role in physical and chemical properties, leading to an increased surface area of powder that can reduce the setting time and increase the microhardness even at lower $\mathrm{pH}$ values after hydration. This fast setting prevents washout or dislodgement of MTA cement in clinical use. The bioactivity of these materials is due to the hydration of the calcium silicate leading to by-products formation. When in contact with the tissue, materials based on calcium silicate form calcium hydroxide and release calcium and hydroxyl ions promoting the increase of $\mathrm{pH}$. The alkaline $\mathrm{pH}$ and the release of calcium ions initially promote a tissue inflammatory response, and later, these ions react with the carbon dioxide present in the tissue, giving rise to calcite crystals, which in turn are related to the decrease of inflammation and deposition of mineralized structures promoting repair (Cintra et al., 2017; Gomes-Filho et al., 2009; Holland et al., 1999).

Every new material needs to be tested priory being launched to the market. The sample of the Nano MTA used in this study was donated by a researcher from the São Paulo State University (UNESP), Ilha Solteira, Brazil. As in any preclinical experimental study, the results of the present investigation should be read with caution since the methodology used has limitations to its application in humans. The use of animals allows investigating different materials under controlled laboratory conditions prior to their use in humans (Browne, 1994). Although these results do not reflect a complete analysis of the reactions that occur in the human conditions, they are significant for the preliminary assessment of the biocompatibility and biomineralization of the tested material.

Considering that Nano MTA presented a biocompatibility and biomineralization capability similar to grey MTA, it seems to be a promising alternative for root canal treatment due to alleged high chemical physical properties as a nanoparticulate material. However, more studies are required to reinforce its physical and biological characteristics. 


\section{Conclusion}

Nano MTA exhibited biocompatibility and biomineralization ability comparable to grey MTA Angelus.

\section{Acknowledgments}

This study was financed in part by the Coordenação de Aperfeiçoamento de Pessoal de Nível Superior - Brasil (CAPES) - Finance Code 001.

\section{References}

Azevedo Queiroz, I. O., Mello, W. G., Martins, C. M., Dal Fabbro, R., Narciso, L. G., Massunari, L., . . Gomes-Filho, J. E. (2018). Systemic bone marker expression induced by grey and white mineral trioxide aggregate in normal and diabetic conditions. International Endodontic Journal. doi:10.1111/iej.12900

Baek, S. H., Plenk, H., Jr., \& Kim, S. (2005). Periapical tissue responses and cementum regeneration with amalgam, SuperEBA, and MTA as root-end filling materials. Journal of Endodontics, 31(6), 444-449. https://www.ncbi.nlm.nih.gov/pubmed/15917684

Browne, R. M. (1994). Animal tests for biocompatibility of dental materials--relevance, advantages and limitations. Journal of Dentistry, 22 Suppl 2, S21-24. doi:10.1016/0300-5712(94)90035-3

Bueno, C. R. E., Vasques, A. M. V., Cury, M. T. S., Sivieri-Araujo, G., Jacinto, R. C., Gomes-Filho, J. E., . . Dezan-Junior, E. (2018). Biocompatibility and biomineralization assessment of mineral trioxide aggregate flow. Clinical Oral Investigations. doi:10.1007/s00784-018-2423-0

Camilleri, J. (2008). The chemical composition of mineral trioxide aggregate. J Conserv Dent, 11(4), 141-143. doi:10.4103/0972-0707.48834

Camilleri, J. (2014). Mineral trioxide aggregate in dentistry: from preparation to application (1st Ed.). New York: Springer-Verlag Berlin Heidelberg.

Cintra, L. T. A., Benetti, F., de Azevedo Queiroz, I. O., de Araujo Lopes, J. M., Penha de Oliveira, S. H., Sivieri Araujo, G., \& Gomes-Filho, J. E. (2017). Cytotoxicity, Biocompatibility, and Biomineralization of the New High-plasticity MTA Material. Journal of Endodontics, 43(5), 774-778. doi:10.1016/j.joen.2016.12.018

Cosme-Silva, L., Benetti, F., Dal-Fabbro, R., Gomes Filho, J. E., Sakai, V. T., Cintra, L. T. A., . . . Viola, N. V. (2019). Biocompatibility and biomineralization ability of Bio-C Pulpecto. A histological and immunohistochemical study. International Journal of Paediatric Dentistry. doi:10.1111/ipd.12464

Cosme-Silva, L., Dal-Fabbro, R., GonÇAlves, L. d. O., Prado, A. S. A. d., Plazza, F. A., Viola, N. V., . . Gomes Filho, J. E. (2019). Hypertension affects the biocompatibility and biomineralization of MTA, High-plasticity MTA, and Biodentine®. Brazilian Oral Research, 33. doi:10.1590/1807-3107bor2019.vol33.0060

Cosme-Silva, L., Gomes-Filho, J. E., Benetti, F., Dal-Fabbro, R., Sakai, V. T., Cintra, L. T. A., . . . Viola, N. V. (2019). Biocompatibility and immunohistochemical evaluation of a new calcium silicate-based cement, Bio-C Pulpo. International Endodontic Journal, 52(5), 689-700. doi:10.1111/iej.13052

Cosme-Silva, L., Santos, A. F. D., Lopes, C. S., Dal-Fabbro, R., Benetti, F., Gomes-Filho, J. E., . . Viola, N. V. (2020). Cytotoxicity, inflammation, biomineralization, and immunoexpression of IL-1beta and TNF-alpha promoted by a new bioceramic cement. J Appl Oral Sci, 28, e20200033. doi:10.1590/1678-7757-2020-0033

Dal-Fabbro, R., Marques de Almeida, M., Cosme-Silva, L., Neto, A. H. C., Salzedas, L. M. P., Cintra, L. T. A., \& Filho, J. E. G. (2019). Chronic alcohol consumption changes blood marker profile and bone density in rats with apical periodontitis. Journal of Investigative and Clinical Dentistry, e12418. doi:10.1111/jicd.12418

Farsi, N., Alamoudi, N., Balto, K., \& Al Mushayt, A. (2006). Clinical assessment of mineral trioxide aggregate (MTA) as direct pulp capping in young permanent teeth. Journal of Clinical Pediatric Dentistry, 31(2), 72-76. Retrieved from https://www.ncbi.nlm.nih.gov/pubmed/17315797

Gomes-Filho, J. E., Rodrigues, G., Watanabe, S., Estrada Bernabe, P. F., Lodi, C. S., Gomes, A. C., . . Silos Moraes, J. C. (2009). Evaluation of the tissue reaction to fast endodontic cement (CER) and Angelus MTA. Journal of Endodontics, 35(10), 1377-1380. doi:10.1016/j.joen.2009.06.010

Hashem, A. A., \& Hassanien, E. E. (2008). ProRoot MTA, MTA-Angelus and IRM used to repair large furcation perforations: sealability study. Journal of Endodontics, 34(1), 59-61. doi:10.1016/j.joen.2007.09.007

Holland, R., de Souza, V., Nery, M. J., Otoboni Filho, J. A., Bernabe, P. F., \& Dezan Junior, E. (1999). Reaction of rat connective tissue to implanted dentin tubes filled with mineral trioxide aggregate or calcium hydroxide. Journal of Endodontics, 25(3), 161-166. doi:10.1016/s0099-2399(99)80134-4

Moreno-Hidalgo, M. C., Caleza-Jimenez, C., Mendoza-Mendoza, A., \& Iglesias-Linares, A. (2014). Revascularization of immature permanent teeth with apical periodontitis. International Endodontic Journal, 47(4), 321-331. doi:10.1111/iej.12154

Nekoofar, M. H., Stone, D. F., \& Dummer, P. M. (2010). The effect of blood contamination on the compressive strength and surface microstructure of mineral trioxide aggregate. International Endodontic Journal, 43(9), 782-791. doi:10.1111/j.1365-2591.2010.01745.x 
Research, Society and Development, v. 10, n. 5, e27710514866, 2021

(CC BY 4.0) | ISSN 2525-3409 | DOI: http://dx.doi.org/10.33448/rsd-v10i5.14866

Olsson, B., Sliwkowski, A., \& Langeland, K. (1981). Subcutaneous implantation for the biological evaluation of endodontic materials. Journal of Endodontics, 7(8), 355-367. doi:10.1016/S0099-2399(81)80057-X

Parirokh, M., Torabinejad, M., \& Dummer, P. M. H. (2018). Mineral trioxide aggregate and other bioactive endodontic cements: an updated overview - part I: vital pulp therapy. International Endodontic Journal, 51(2), 177-205. doi:10.1111/iej.12841

Recommended standard practices for biological evaluation of dental materials. Federation Dentaire International, Commission of Dental Materials, Instruments, Equipment and Therapeutics. (1980). International Dental Journal, 30(2), 140-188. https://www.ncbi.nlm.nih.gov/pubmed/6931825

Sales, L. S., Santos, A. D. d., Cosme-Silva, L., Queiroz, I. O. d. A., Martins, C. M., Dal-Fabbro, R., ... Gomes Filho, J. E. (2021). Influence of the Vehicle on the Tissue Reaction and Biomineralization of Fast Endodontic Cement. Pesquisa Brasileira em Odontopediatria e Clinica Integrada, 21. doi:10.1590/pboci.2021.053

Simon, S., Rilliard, F., Berdal, A., \& Machtou, P. (2007). The use of mineral trioxide aggregate in one-visit apexification treatment: a prospective study. International Endodontic Journal, 40(3), 186-197. doi:10.1111/j.1365-2591.2007.01214.x

Torabinejad, M., Parirokh, M., \& Dummer, P. M. H. (2018). Mineral trioxide aggregate and other bioactive endodontic cements: an updated overview - part II: other clinical applications and complications. International Endodontic Journal, 51(3), 284-317. doi:10.1111/iej.12843

Viola, N. V., Guerreiro-Tanomaru, J. M., da Silva, G. F., Sasso-Cerri, E., Tanomaru-Filho, M., \& Cerri, P. S. (2012). Biocompatibility of an experimental MTA sealer implanted in the rat subcutaneous: quantitative and immunohistochemical evaluation. J Biomed Mater Res B Appl Biomater, 100(7), 1773-1781. doi:10.1002/jbm.b.32744Put space between one reference and another. 